E Q U I L I B R I U M

Volume 6 IsSue 1, 2011

IS S N $1689-765 \mathrm{X}$

Maria Kola-Bezka

Nicolaus Copernicus University in Toruń, Poland

\title{
Creativity as a Factor for Socio-Economic Development of Polish Regions
}

JEL Classification Codes: $R 100$

Keywords: regional creativity, socio-economic development

\begin{abstract}
This article aims to verify the hypothesis that creativity is an important factor for socio-economic development of Polish regions. The first part of the paper clarifies the idea of regional creativity, its factors and method of measurement. Following two parts present methodology and results of the research concerning creativity and development which uses multivariate comparative analysis. The next one examines relationship between these phenomena. The research revealed that there is strong correlation between the level of creativity and socioeconomic development of regions in Poland. In addition, there are large disparities in the level of creativity of these regions. It may be one of the reasons for persistence and even deepening of interregional differences in the level and dynamics of socio-economic development of these regions in the future.
\end{abstract}

\section{Introduction}

Creativity is a concept that occurred recently in actions to intensify the development of European Union regions and to increase their economic and social cohesion. Its great importance was emphasized by the announcement of the year 2009 as the European Year of Creativity and Innovation.

The explanatory memorandum stressed that in order to improve the quality of life of the EU regional communities it is necessary to create innovation in the regions, and the condition of their creation is just creativity. Creativity in this approach was treated as a key prerequisite for economic development understood in both economic and social terms. This assumption, however, has not been verified empirically. Making such verification would be of particular importance es- 
pecially in the regions of Central and Eastern Europe. They are in most cases lagging behind compared to other regions of the EU, so if creativity is important factor for their development, creating conducive environment to creativity would be as important activity of development policy as investing in technical and social infrastructure, building the diverse structure of the economy, including the promotion of a knowledge-based sectors of the economy, creating conducive conditions to formation and functioning of entrepreneurship, developing business environment institutions and activating local and regional authorities to create the right climate for business.

The aim of this paper is to verify the hypothesis that creativity is an important factor for socio-economic development of Polish regions. The object of the analysis are NUTS 2 regions in Poland, as representatives of the regions of Central and Eastern Europe. Regional creativity, as well as socio-economic development of the region are multifaceted phenomena, hence the starting point in a research designed to confirm or deny the existence of dependencies between them was measuring them using the synthetic indicator that takes into account many of the characteristics of these phenomena simultaneously. This measure was also used to diagnose the differences in the level of creativity of the regions. In case of positive verification of the hypothesis, awareness of these differences and understanding their causes would be a condition for effective action to reduce disparities in socio-economic development of the regions, involving the strengthening of specific circumstances of regional creativity. The research was conducted using multivariate comparative analysis.

\section{Factors of regional creativity and method of its measurement}

In traditional way creativity is a human characteristic that manifests itself in many fields and contexts, from works of art, design and craft to scientific breakthroughs and entrepreneurship. It is identified with contrivance, originality, nonconformity and strong tendency to take a risk. A creative person is able to incessantly propose something new and valuable. Moreover, creativity can be analyzed as a process of imaginative thinking and creating something new and valuable. In economic sciences it is usually considered in micro scale as an element of competitiveness potential of organizations - a resource which can not be copied and stolen. These characteristics mean that creativity is a resource which enables to produce a unique product. Nowadays creativity begins to be perceived as an important resource of a region which enables to compete effectively in order to gain other resources used to improve the level of life of regional communities and increase competitiveness of the European economy (Commission of the European Communities 2008). 
Villalba pointed out that in order to set down regional creativity factors it is useful to employ an approach of Florida named sector approach of creativity or three T's model (Villalba 2008, p. 10-13; 2010). Florida presented creativity as a motor force of economic growth which decides about the economic success of cities and highly urbanized places. The success is associated with a number of creative people that these places are able to attract and stem from the fact that these are places free from prejudices, developing new technologies, offering favorable conditions to develop talents and diverse in many respects. The places provide environment that harnesses human creativity and turns it into economic value (Florida 2002). Creativity is a broad social process and requires teamwork. It is driven by exchange of views and cooperation. People can no longer prosper and grow by trapping and rewarding the creative talents of minority. If regions are to truly prosper, everyone must be brought fully into the system by employing them to do more value-adding creative work. Doing so will raise people wages and strengthen national economy, while also helping to bring regional economies into better balance (Florida, Tinagli 2004, p. 11, 44).

In this approach the country or region ability to compete in global economy goes beyond trade in goods and services and attracting financial capital and investment. It entails more and more ability to attract creative people, keep them in the places and ensure them personal development in tolerant and diversified environment. The traditional model assumes that the source of economic growth and development are enterprises, and technologies need to be supplemented with these elements. The region must have all three T's (Technology, Talent, Tolerance) to be attractive to creative people, generate innovation and stimulate economic growth.

In order to measure regional creativity Florida has proposed a composite indicator, the creativity index. This index, based on indicators of technology, talent and tolerance, takes into account key factors of creativity which are important for economic growth: the presence in the region of high-tech enterprises and their production of patents, number of people in the "creative class" ${ }^{1}$ and openness of a place to new ideas and people who are not subject to conformity (table 1).

${ }^{1}$ Creative class is a group of people with creative occupations. Creative class consists of: creative core, creative professionals and bohemians. Creative core is formed by e.g. physicists, chemists, mathematicians, statisticians, computing professionals, engineers, university and higher education teaching professionals, social sciences professionals and public service administrative professionals. The group of creative professionals consists of e.g. legislators, senior officials and managers, business professionals, physical and engineering science associate professionals, finance and sales associate professionals, business services agents, trade brokers, police inspectors and detectives and social work associate professionals. Bohemians are writers and creative or performing artists, photographers and image and sound recording equipment operators, artistic, entertainment and sports associate professionals, fashion and other models (Boschma, Fritsch 2007, p. 246). 
Table 1. List of indicators and their descriptions which constitute creativity index

\begin{tabular}{|c|c|c|}
\hline Index & Sub-indexes & Description \\
\hline \multirow{3}{*}{ Talent } & Creative Class & $\begin{array}{c}\text { Employed in creative occupations as percentage } \\
\text { of total employment }\end{array}$ \\
\hline & Human Capital & $\begin{array}{c}\text { Percentage of population 25-64 with a bachelor } \\
\text { degree or above }\end{array}$ \\
\hline & Scientific Talent & $\begin{array}{l}\text { Number of researchers in scientific disciplines } \\
\text { per thousand workforce }\end{array}$ \\
\hline \multirow{3}{*}{ Technology } & Innovation Index & $\begin{array}{l}\text { Patents applications to the US Patent Office per } \\
\text { million population }\end{array}$ \\
\hline & $\begin{array}{l}\text { Technology Innovation } \\
\text { Index }\end{array}$ & $\begin{array}{l}\text { High-Tech Patents applications to the US Patent } \\
\text { Office per million population }\end{array}$ \\
\hline & R\&D Index & R\&D expenditure as percentage of GDP \\
\hline \multirow{3}{*}{ Tolerance } & Attitudes Index & $\begin{array}{l}\text { Percentage of population that express tolerant } \\
\text { attitudes toward minorities }\end{array}$ \\
\hline & Values Index & $\begin{array}{c}\text { Degree to which a country is based on traditional } \\
\text { values versus more rational/secular values }\end{array}$ \\
\hline & Self Expression Index & $\begin{array}{l}\text { Degree to which a country recognizes and } \\
\text { accepts self expression values }\end{array}$ \\
\hline
\end{tabular}

Source: R. Florida, I. Tinagli, Europe in the Creative Age, Carnegie Mellon, Software Industry Centre, Demos, February 2004, p. 44.

The advantage of the creativity index is taking into account immaterial elements of regional creativity such as degree of tolerance of its inhabitants to variety of differences, degree to which a community is based on traditional values and characteristics of individuals making up the potential of success including self-expression and self-interests. It is also its drawback. There is, in fact, lack of widely available and comparable data which could be a basis for measuring the indices of tolerance and thereupon also creativity indexes for different regions. Therefore it is impossible to interpret differences in their levels.

Given these constraints, the measurement of creativity of Polish regions was carried out using multivariate comparative analysis which takes into account many dimensions (characteristics) of this phenomenon simultaneously. Data which was used concerned innovation and entrepreneurship and was available in public statistics. It can be attributed to three groups of determinants of creativity, as indicated by Florida: conditions related to talent, technology and tolerance. The assumption was that creativity as a personal attribute is a necessary condition and creative activities are starting point in case of both, creating innovation (proposing something new or significantly improved, having a value that is filling the market gap, solving a problem) and developing entrepreneurship (that is ability to use emerging opportunities and transform them into concrete economic results). 


\section{Measurement of creativity of Polish regions}

Measurement of the level of Polish regions' creativity was based on data of Central Statistical Office in Poland garnered in Bank of Regional Data and Eurostat concerning the year 2007. A collection of potential variables consisted of 24 innovation and entrepreneurship indicators (table 2).

Table 2. Potential variables which define creativity of Polish regions

\begin{tabular}{|c|c|}
\hline Symbol & Description \\
\hline $\mathrm{X} 1$ & $\begin{array}{l}\text { Lifelong learning - participation of adults aged } 25-64 \text { in education and training } \\
\text { per } 1000 \text { population }\end{array}$ \\
\hline $\mathrm{X} 2$ & Patents applications per million population \\
\hline $\mathrm{X} 3$ & R\&D expenditures as percentage of GDP \\
\hline $\mathrm{X} 4$ & Researchers as $\%$ of total employed \\
\hline $\mathrm{X} 5$ & Students in all levels of education, as percentage of total population \\
\hline $\mathrm{X} 6$ & Students in tertiary education, as percentage of the population aged 20 to 24 \\
\hline $\mathrm{X} 7$ & $\begin{array}{l}\text { Educational attainment level - percentage of the population aged 25-64 having } \\
\text { completed tertiary education }\end{array}$ \\
\hline $\mathrm{X} 8$ & $\begin{array}{l}\text { Employment in high and medium high-tech manufacturing, as percentage of total } \\
\text { employment }\end{array}$ \\
\hline X9 & $\begin{array}{l}\text { Human resources in science and technology by virtue of occupation, as percentage } \\
\text { of active population }\end{array}$ \\
\hline $\mathrm{X} 10$ & Number of arrivals at hotels per capita \\
\hline $\mathrm{X} 11$ & People born abroad as percentage of the $\mathrm{p}$ \\
\hline $\mathrm{X} 12$ & Growth rate of number of enterprises in the years $2002-2007$, in $\%$ \\
\hline $\mathrm{X} 13$ & Enterprises registered in REGON per 10 thousands population \\
\hline $\mathrm{X} 14$ & Enterprises newly registered in the REGON register per 10 thousands population \\
\hline $\mathrm{X} 15$ & Enterprises removed from the REGON register per 10 thousands population \\
\hline $\mathrm{X} 16$ & $\begin{array}{l}\text { Number of newly registered entities with foreign capital per } 100 \text { thousands } \\
\text { population }\end{array}$ \\
\hline $\mathrm{X} 17$ & Growth rate of R\&D expenditures per 1 inhabitant in the years $2002-2007$, in $\%$ \\
\hline $\mathrm{X} 18$ & Gross education ratio - basic vocational schools (aged 16-18 years) \\
\hline $\mathrm{X} 19$ & Gross education ratio - general secondary schools (aged 16-18 years) \\
\hline $\mathrm{X} 20$ & Gross education ratio - post secondary schools (aged 19-21 years) \\
\hline $\mathrm{X} 21$ & $\begin{array}{l}\text { Percentage of primary schools for children and youth, excluding special, with } \\
\text { computers used for students' Internet access }\end{array}$ \\
\hline $\mathrm{X} 22$ & $\begin{array}{l}\text { Percentage of lower secondary schools for children and youth, excluding special, } \\
\text { with computers used for students' Internet access }\end{array}$ \\
\hline $\mathrm{X} 23$ & $\begin{array}{l}\text { Number of pupils per } 1 \text { computer Internet access used for students in primary } \\
\text { schools, excluding special }\end{array}$ \\
\hline $\mathrm{X} 24$ & $\begin{array}{l}\text { Number of pupils per } 1 \text { computer Internet access used for students in lower } \\
\text { secondary schools, excluding special }\end{array}$ \\
\hline
\end{tabular}

Source: own work. 
Technological factors of creativity were: X2, X3, X12, X13, X14, X15, i X17. Variables which determine the level of tolerance were: X11 i X16. Variables describing the ability of regions to maintain and develop talented people were: $\mathrm{X} 1$, X4, X5, X6, X7, X8, X9, X10, X18, X19, X20, X21, X22, X23 and X24.

A set of potential variables was reduced on the basis of variation coefficient whose threshold level equaled $10 \%$ and correlation coefficient which critical level was set at 0.6 . Finally, a set of diagnostic variables numbered 13 variables: X2, X6, X8, X9, X10, X11, X12, X14, X16, X17, X18, X20, X23. All of them were stimulants with the same importance from the viewpoint of their impact on creativity. The next step of the procedure was normalization. Taking into account that the method of normalization influences the results of the research and its conclusions, normalization of diagnostic variables was done by using three formulas ${ }^{2}$. The results of normalization were used to calculate six intermediate taxonomic indicators of creativity (three of them were calculated using the Hellwig method with Euclidean distance; another three were calculated using nonmodel method). Six intermediate taxonomic indicators of creativity were used to calculate synthetic taxonomic measure of creativity according to the formula: where - normalized value of intermediate taxonomic indicator of creativity (Piotrowska-Trybull, Reniecki 2006, p. 273; Kosiedowski 2008, p. 161).

Synthetic taxonomic measure of creativity was used to rank regions according to their level of creativity and group them in classes of regions with similar levels of creativity. Table 3 presents the results of ranking and grouping.

Mazowieckie, which was placed first, was a region with the largest number of students in tertiary education as percentage of the population aged 20 to 24 and the largest human resources in science and technology by virtue of occupation as percentage of active population. It had also the highest growth rate of number of enterprises in the years 2002-2007 and the largest number of newly registered entities with foreign capital per 100 thousands population. It took second place in terms of patents applications per million population and third place in terms of enterprises newly registered in the REGON register per 10 thousands population. This was accompanied by further places of Mazowieckie in terms of growth rate of R\&D expenditures per 1 inhabitant in the years $2002-2007\left(10^{\text {th }}\right.$ place), employment in high and medium high-tech manufacturing as percentage of total employment $\left(11^{\text {th }}\right)$, gross education ratio in post secondary schools $\left(12^{\text {th }}\right.$ ) and gross education ratio in basic vocational schools $\left(15^{\text {th }}\right)$.

${ }^{2}$ Following formulas were used in the normalization of diagnostic variables: $\mathrm{z}=, \mathrm{z}=,=$ (which means formulas: standardization, unitarization and normalization), where: $z_{i j}$ - normalized value of the $j$-th variable for the $i$-th object, $x_{i j}$ - value of $j$-th variable for $i$-th object, arithmetic mean of variable $x_{j}, s_{j}$ - standard deviation of $j$-th variable. 
Table 3. Ranking and classification of Polish regions by the level of creativity

\begin{tabular}{|l|c|c|c|}
\hline \multicolumn{1}{|c|}{ Region } & $\mathbf{D}_{\mathbf{i}}$ & $\begin{array}{c}\text { Rank according } \\
\text { to the value of } \mathbf{D}_{\mathbf{i}}\end{array}$ & Class \\
\hline Mazowieckie & 0.9627 & 1 & $\mathrm{I}$ \\
Dolnośląskie & 0.9090 & 2 & \\
Pomorskie & 0.8513 & 3 & II \\
\hline Wielkopolskie & 0.7107 & 4 & \\
Małopolskie & 0.7080 & 5 & III \\
Zachodniopomorskie & 0.6405 & 6 & \\
Lódzkie & 0.5897 & 7 & \\
Śląskie & 0.4861 & 8 & IV \\
\hline Lubuskie & 0.4816 & 9 & \\
Opolskie & 0.4392 & 10 & 11 \\
Warmińsko-Mazurskie & 0.2935 & 12 & \\
\hline Świętokrzyskie & 0.2853 & 13 & \\
Lubelskie & 0.2269 & 14 & \\
Kujawsko-pomorskie & 0.1940 & 16 & \\
Podkarpackie & 0.1752 & & \\
Podlaskie & 0.0000 & & \\
\hline
\end{tabular}

$\mathrm{D}_{\mathrm{i}}$ - synthetic taxonomic measure of creativity. I - class of regions with the highest levels of creativity. II - class of regions with medium levels of creativity. III - class of regions with low levels of creativity. IV - class of regions with the lowest levels of creativity.

Source: own work.

Dolnośląskie was characterized by the largest number of patents applications per million population. It took second place in terms of employment in high and medium high-tech manufacturing as percentage of total employment and the number of newly registered entities with foreign capital per 100 thousands population and third place in terms of students in tertiary education as percentage of the population aged 20 to 24 and number of arrivals to hotels per capita.

Pomorskie was at the forefront of Polish regions in terms of employment in high and medium high-tech manufacturing as percentage of total employment ( $1^{\text {st }}$ place), number of enterprises newly registered in the REGON register per 10 thousand population and growth rate of R\&D expenditures per 1 inhabitant in the years 2002-2007 (in both cases it took $2^{\text {nd }}$ place) and human resources in science and technology by virtue of occupation as percentage of active population ( $3^{\text {rd }}$ place). However, Pomorskie was characterized by lower values of other variables constituting creativity. Therefore, in ranking of regions according to the level of creativity it took only third place.

Other regions took further places in terms of values of variables which determine regional creativity, hence the values of their synthetic taxonomic meas- 
ures of creativity have allowed to classify these regions for further positions in the general ranking. It is worth mentioning, however, that in class II, III and IV there were regions which were characterized by the highest or one of the highest values of certain characteristics that determine the level of creativity. In class II there were the following regions: Małopolskie, Zachodniopomorskie and Łódzkie. Małopolskie took first place in the ranking in terms of number of arrivals at hotels per capita, second place in terms of students in tertiary education as percentage of the population aged 20 to 24 and third place in terms of patents applications per million population. Zachodniopomorskie was placed first in terms of number of enterprises newly registered in the REGON register per 10 thousands population and third in terms of employment in high and medium high-tech manufacturing as percentage of total employment. Lódzkie took first place in terms of people born abroad as percentage of the population aged 18-64 and gross education ratio in post secondary schools. In class III Opolskie was the region which stood out from other regions because of its second place in ranking in terms of people born abroad as percentage of the population aged 18-64 and growth rate of number of enterprises in the years 2002-2007. In class IV the regions which stood out from others were Lubelskie, Kujawsko-Pomorskie and Świętokrzyskie. Lubuskie was characterized by the largest number of pupils per 1 computer Internet access used for students in primary schools. Kujawsko-Pomorskie had the highest level of gross education ratio in basic vocational schools. Świętokrzyskie took first place in the ranking in terms of growth rate of R\&D expenditures per 1 inhabitant in the years 2002-2007.

\section{Measurement of socio-economic development of Polish regions}

Socio-economic development of the region, as well as regional creativity, is multifaceted and complex category. Therefore, to measure the level of socioeconomic development of Polish regions the multivariate comparative analysis was used. The research was conducted based on data concerning the year 2007 collected by Central Statistical Office and Eurostat.

The analysis began with the selection of potential variables describing the object of the study (table 4). A set of potential variables was reduced on the basis of variation coefficient which the lowest level equaled $10 \%$ and correlation coefficient whose critical level equaled 0.7. Finally, a set of diagnostic variables numbered 7 variables: X1, X4, X5, X8, X9, X11, X14. Two of them (X9 i X11) were transformed into stimulants. Diagnostic variables were arbitrarily assigned different weights reflecting their impact on socio-economic development of Polish regions ( 0.2 for X1, X9 i X11; 0.1 for other variables). 
Table 4. Potential variables which define socio-economic development of Polish regions

\begin{tabular}{|l|l|}
\hline Symbol & \multicolumn{1}{|c|}{ Description } \\
\hline X1 & GDP per inhabitant in current prices, in PLN \\
\hline X2 & GDP per person employed in current prices, in thousands of PLN \\
\hline X3 & Average annual growth of real GDP in the years 1995-2007, in \% \\
\hline X4 & The share of service sector in total employment, in \% \\
\hline X5 & R\&D expenditures as percentage of GDP \\
\hline X6 & R\&D expenditures in enterprises sector as percentage of GDP \\
\hline X7 & Employment rate in the population aged 15-64, in \% \\
\hline $\mathbf{X 8}$ & Average annual population decline in the years 1995-2007, in \% \\
\hline $\mathbf{X} 9$ & Registered unemployment rate, in \% \\
\hline $\mathbf{X 1 0}$ & Registered unemployment rate of women, in $\%$ \\
\hline $\mathbf{X 1 1}$ & Registered unemployment rate of youth aged 15-24, in \% \\
\hline $\mathbf{X 1 2}$ & The share of long-term unemployment in total unemployment, in \% \\
\hline $\mathbf{X 1 3}$ & People aged 15-64 as percentage of total population \\
\hline $\mathbf{X 1 4}$ & People having tertiary education completed as percentage of population aged 25-64 \\
\hline
\end{tabular}

Source: own work on the basis of: W. Kosiedowski, Regiony Europy Srodkowo-Wschodniej w procesie integracji ze szczególnym uwzględnieniem wschodniego pogranicza Unii Europejskiej, Wydawnictwo Naukowe UMK, Toruń 2008, p. 158.

As in the study of creativity in the regions, the variables were normalized in three ways which were used for setting six intermediate taxonomic indicators of socio-economic development. The synthetic taxonomic measure of development which was calculated on the basis of intermediate indicators, was used to rank Polish regions by the level of socio-economic development and to classify them into groups of regions with similar level of the development. Table 5 presents the results of ranking and grouping.

Class I, which groups regions with the highest level of socio-economic development, consists of only one region - Mazowieckie. It was characterized by the highest GDP per inhabitant in current prices among all the regions, the largest share of service sector in total employment, the largest R\&D expenditures as percentage of GDP and the largest share of people having tertiary education completed in population aged 25-64. Mazowieckie was one of four regions where there has been average annual population growth in the years 1995-2007, behind only Małopolskie. It was also characterized by one of the lowest registered unemployment rates (it took third place in that respect) but the registered unemployment rate of youth aged 15-24 has allowed to classify the region on the seventh position.

The group of regions with medium levels of socio-economic development consists of six regions. Among them, the highest level of development characterized Wielkopolskie. Further positions were taken by: Pomorskie, Małopolskie, 
Table 5. Ranking and classification of Polish regions by the level of socio-economic development

\begin{tabular}{|l|c|c|c|}
\hline Region & & $\begin{array}{c}\text { Rank according to } \\
\text { the value of }\end{array}$ & Class \\
\hline Mazowieckie & 1.0000 & 1 & I \\
\hline Wielkopolskie & 0.6730 & 2 & \\
Pomorskie & 0.6525 & 3 & \\
Małopolskie & 0.6208 & 4 & II \\
Śląskie & 0.4236 & 5 & \\
Dolnośląskie & 0.3904 & 6 & \\
Lódzkie & 0.3631 & 7 & \\
\hline Podlaskie & 0.3241 & 8 & \\
Zachodniopomorskie & 0.2576 & 9 & \\
Opolskie & 0.2476 & 10 & \\
Lubuskie & 0.2451 & 11 & \\
Kujawsko-pomorskie & 0.2275 & 12 & \\
\hline Podkarpackie & 0.2163 & 13 & \\
Lubelskie & 0.1770 & 14 & \\
Warmińsko-Mazurskie & 0.0914 & 15 & \\
Świętokrzyskie & 0.0000 & 16 & \\
\hline
\end{tabular}

$\mathrm{W}_{\mathrm{i}}$ - synthetic taxonomic measure of socio-economic development. I - class of regions with the highest levels of socio-economic development. II - class of regions with medium levels of socio-economic development. III - class of regions with low levels of socio-economic development. IV - class of regions with the lowest levels of socio-economic development.

Source: own work.

Śląskie, Dolnośląskie i Łódzkie. Wielkopolskie was placed second in general ranking of regions by level of socio-economic development because of the lowest registered unemployment rate and in terms of high GDP per inhabitant in current prices and relatively low registered unemployment rate of youth aged 15-24. Wielkopolskie took fourth place in terms of R\&D expenditures as percentage of GDP and was last in group of regions with average annual population growth in the years 1995-2007. In terms of the share of service sector in total employment Wielkopolskie was eleventh and in terms of number of people having tertiary education completed in population aged 25-64 was twelfth. Pomorskie was among the top three regions in terms of the share of service sector in total employment and average annual population growth in the years 1995-2007. It took fifth place in terms of GDP per inhabitant in current prices, sixth in terms of R\&D expenditures as percentage of GDP, registered unemployment rate and registered unemployment rate of youth aged 15-24 and seventh in terms of people having tertiary education completed as percentage of population aged 25-64. In the group of other regions with medium levels of socio-economic develop- 
ment particular attention should be paid to Małopolskie and Śląskie. Małopolskie was characterized by the highest average annual population growth in the years 1995-2007 and took second place in terms of R\&D expenditures as percentage of GDP and registered unemployment rate. Śląskie had the lowest registered unemployment rate of youth aged 15-24 among Polish regions.

Class III consists of 5 regions with low levels of socio-economic development: Podlaskie, Zachodniopomorskie, Opolskie, Lubuskie and KujawskoPomorskie. They were generally characterized by average or low values of indicators of the development. The exceptions were third place of Podlaskie in terms of number of people having tertiary education completed in population aged 25-64, second place of Zachodniopomorskie in terms of the share of service sector in total employment, fourth place of this region in terms of number of people having tertiary education completed in population aged 25-64 and third place of Opolskie in terms of registered unemployment rate of youth aged 15-24.

Regions with the lowest levels of socio-economic development were: Podkarpackie, Lubelskie, Warmińsko-mazurskie and Świętokrzyskie. In class IV special attention should be paid to Podkarpackie and Lubelskie. Podkarpackie was characterized by the lowest average annual population decline in the years 1995-2007. Lubelskie, in spite of its general position in ranking of Polish regions by the level of socio-economic development, took third place among all the regions in terms of R\&D expenditures as percentage of GDP and sixth place in terms of number of people having tertiary education completed in population aged 25-64.

\section{Identification and analysis of the relationship between creativity and socio-economic development of Polish regions}

The research of creativity and socio-economic development of Polish regions revealed that the regions, which were ranked high in the ranking of creativity, were also leaders in terms of socio-economic development, while those whose level of creativity was low, were characterized by the low level of development. The exception was Podlaskie, which was ranked last in the ranking of creativity and eight in the ranking of development. This could mean that there were factors which have a stronger impact on socio-economic development of this region than creativity.

Generally, western regions of Poland are more creative than eastern regions. Western regions are more industrialized and with a greater share of services than eastern regions. Therefore, there are stronger technological indication of creativity. In addition, the western regions create better conditions to attract, develop and maintain talented people and are thus more attractive to the creative class. 
They have a better developed social and technical infrastructure, which also favors the development of creativity.

It also appears that the western regions because of their location are more tolerant toward diversity. Compared to the regions of Eastern Poland, in the west live relatively more people of working age who were born abroad. It is probably related to the fact that these regions due to the relatively higher level of development, offer better conditions to live and work. They are also culturally closer to Western Europe. There are more companies with foreign capital, which is related both to the quality of technical and social infrastructure of these regions, proximity to markets of the EU-15 and the development potential of regional markets. East Polish regions are inhabited by residents with lower average incomes, there is bigger unemployment and there are accumulated various social problems associated with it.

The relationship between the level of creativity and the level of socio-economic development can be measured using the Pearson's correlation coefficient. Additionally, to explain what part of the change in the dependent variable (effect) determines the changes in the independent variable (cause) one can use the coefficient of determination. For a synthetic taxonomic measure of creativity and a synthetic taxonomic measure of socio-economic development of Polish regions the Pearson's correlation coefficient was equal to 0.74. It indicates a positive, strong relationship between the regions' creativity and their socio-economic development. Thereupon regional creativity can be treated as an important factor of development. However, the relationship between the level of creativity and level of socio-economic development is reciprocal. It means that creative regions offer better conditions of socio-economic development, hence their level of development is generally higher than in the regions which are less creative. Meanwhile, in the more developed regions there are better conditions conducive to the development of creativity, than in less developed regions.

The coefficient of determination, which is the square of the Pearson's correlation coefficient, accounted for $54.8 \%$. Treating creativity as a factor of socioeconomic development, it can be interpreted as follows: over half of the changes in the socio-economic development of Polish regions is determined by changes in regional creativity.

\section{Conclusion}

Positive verification of the hypothesis that creativity is an important factor for socio-economic development of Polish regions means that the occurrence of interregional disparities in the level of creativity is associated with the existence of significant disparities in development potential of Polish regions. This could mean that, in the future, economic results of the regions and the social con- 
ditions which they offer, will be also characterized by considerable diversity. Awareness of the existence, extent and causes of the differences in the level of regional creativity can be helpful for conducting long-term development activities not only at the national level, but also at European Union level. It appears, however, that differences in the level of regional creativity are not only the domain of Poland.

The results of the study indicate that in Poland, Capital Region and western regions have the highest creativity among regions. On their territories there are focused centers of power, business, culture and entertainment. They are large markets and have rich resources of human capital. Therefore, they are attractive to both, investors investing capital in innovative projects and creative people open to new ideas. Major challenge faced in this regard by the regions of Eastern Poland is that they are poor in those reSources: They are particularly vulnerable because of their peripherality, relatively small population and large proportion of agricultural land. For this reason, it seems that in these regions actions aimed at stimulating creativity should be based on the construction of educational and social infrastructure conducive to the development of talented people and shaping social attitudes favoring unconventional but creative behavior, accepting different types of diversity, including cultural and philosophical, and expressing the desire to continuously improve knowledge.

\section{Literature}

Boschma R. A., Fritsch M. (2007), Creative Class and Regional Growth in Europe. Empirical Evidence from Eight European Countries, „The Jena Economic Research Papers”.

Commission of the European Communities (2008), Proposal for a Decision of the European Parliament and of the Council concerning the European Year of Creativity and Innovation (2009).

Florida R. (2002), The Rise of the Creative Class: And How It's Transforming Work, Leisure, Community and Everyday Life, Basic Books, New York.

Florida R., Tinagli I. (2004), Europe in the Creative Age, Carnegie Mellon, Software Industry Centre, Demos.

Kosiedowski W. (2008), Regiony Europy Środkowo-Wschodniej w procesie integracji ze szczególnym uwzględnieniem wschodniego pogranicza Unii Europejskiej, Wydawnictwo Naukowe Uniwersytetu Mikołaja Kopernika w Toruniu, Toruń.

Piotrowska-Trybull M., Reniecki P. (2006), Konkurencyjność polskich regionów wobec wyzwań globalizacji, [in:] Karaszewski W., Kunikowski S. (ed.), Polityka rozwoju państw Europy Środkowo-Wschodniej. Aspekty makroekonomiczne i regionalne, Oficyna Wydawnicza LEGA, Włocławek.

Pluta W. (1977), Wielowymiarowa analiza porównawcza w badaniach ekonomicznych, Państwowe Wydawnictwo Ekonomiczne, Warszawa.

Pociecha J., Podolec B., Sokołowski A., Zając K. (1988), Metody taksonomiczne w badaniach społeczno-ekonomicznych, Państwowe Wydawnictwo Naukowe, Warszawa. 
Villalba E. (2010), Monitoring Creativity at an Aggregate Level: a proposal for Europe, „European Journal of Education”, vol. 45, No. 2, Part I.

Villalba E. (2008), On Creativity. Towards an Understanding of Creativity and its Measurements, JRC Scientific and Technical Reports, European Communities, Luxembourg. 